\title{
Analysis of the Quality of Used Cooking Oil Used in Frying Chicken
}

\author{
Dian I. Sinurat and Ramlan Silaban* \\ Department of Chemistry, Faculty of Mathematics and Sciences, Medan State University, Medan 20221, \\ Indonesia \\ *Email: drrsilabanmsi@yahoo.co.id
}

\begin{abstract}
This study aims to determine the quality of oil quality that is used repeatedly by frying chicken with the SNI. Bulk oil is used for frying the chicken with 11 frying repetitions. Repetition of oil before frying, repeat 1 time frying up to 10 frying times. Then the oil is tested for water content, Free Fatty Acid (FFA), peroxide value and iodine value. From this study, the quality of cooking oil was obtained for the range of: water content 0.03$1.04 \%(w / w)$, Free Fatty Acids (FFA) 0.39-1.01\%(w/w), peroxide value 5,99-18,465 mekO2/kg, iodine value 3.255-3.55 gI2/100g oil. Based on the various tests, the water content up to the oil from frying 3, Free Fatty Acid to oil from frying 3, the peroxide value to frying oil 4 still meets the SNI 01-3741-2013 oil quality standard. And in the iodine value test, all repeated frying results still meet the SNI 01-3741-2013 oil quality standard.
\end{abstract}

Keywords: cooking oil, water content, Free Fatid Acids (FFA), peroxide number, iodine number

\section{Pendahuluan}

Minyak goreng merupakan salah satu kebutuhan pokok masyarakat dalam memenuhi kebutuhan hidup sehari-hari. Kurang lebih 290 juta ton minyak dikonsumsi tiap tahun. Ketaren melaporkan bahwa banyaknya permintaan akan bahan pangan digoreng merupakan suatu bukti yang nyata mengenai betapa besarnya jumlah bahan pangan digoreng yang dikonsumsi manusia oleh lapisan masyarakat dari segala tingkat usia. ${ }^{1}$ Minyak goreng yang dikonsumsi sehari-hari sangat erat kaitannya dengan kesehatan. Karena sebagian kecil minyak goreng akan diserap oleh bahan pangan yang di goreng, sehingga kualitas minyak goreng akan mempengaruhi cita rasa makanan yang digoreng, dan juga mempengaruhi kesehatan.

Menurut Kapitan minyak goreng dapat digunakan hingga 3-4 kali penggorengan. ${ }^{2}$ Akan tetapi, jika minyak goreng digunakan berulang kali, maka asam lemak yang terkandung akan semakin jenuh dan akan berubah warna. Kusumaningtyas menyatakan bahwa minyak goreng bekas tersebut dikatakan telah rusak atau dapat disebut minyak jelantah dan kurang baik untuk dikonsumsi.3 Menurut Syafiq minyak jelantah yang dipakai berkali-kali akan meningkatkan asam lemak bebas, dan hal ini akan menyebabkan bau yang tengik, bahan gorengan kurang menarik, cita rasa tidak enak, terjadi kerusakan vitamin dan asam lemak esensial.5 Selain itu, penggorengan makanan pada suhu tinggi, yang dilakukan dengan menggunakan minyak yang memiliki kadar asam lemak jenuh yang tinggi, mengakibatkan makanan menjadi berbahaya bagi kesehatan. Selain itu, pemanasan minyak goreng yang lama dan berulang akan menghasilkan senyawa peroksida, senyawa peroksida ini merupakan radikal bebas yang bersifat racun bagi tubuh. Kusumaningtyas 
menyatakan bahwa batas maksimal bilangan peroksida dalam minyak goreng yang layak dikonsumsi manusia adalah $10 \mathrm{meq} / \mathrm{kg}$ minyak goreng. Minyak goreng bekas yang terserap oleh makanan yang digoreng dan termakan oleh manusia akan masuk dan dicerna di dalam tubuh manusia. ${ }^{3,4}$

Menurut Ardhany bahwa minyak goreng bekas yang masuk ke dalam tubuh manusia ini jika dibiarkan bertahun-tahun menumpuk di dalam tubuh akan membahayakan karena mengandung asam lemak jenuh yang sangat tinggi, serta akan menimbulkan berbagai penyakit penyebab kematian bagi manusia seperti penyakit jantung koroner, stroke, meningkatnya kadar lipida utamanya kolesterol darah, hipertensi, bahkan dapat memicu terjadinya kanker, meskipun efeknya akan terlihat dalam jangka panjang. ${ }^{6}$

Zahra melaporkan bahwa untuk mengetahui kualitas minyak goreng dapat diuji dengan metode analisis kadar air, bilangan asam, kadar asam lemak bebas, dan bilangan peroksida. Analisis kualitas minyak secara kimiawi dilakukan dengan menguji bilangan peroksida, bilangan asam dan kadar asam lemak bebas. ${ }^{7,8}$

Berdasarkan informasi yang telah dikemukakan diatas maka akan dilakukan pengamatan mutu minyak goreng dalam penggorengan ayam krispi dengan perlakuan 0 kali penggorengan (sebelum penggorengan), pengulangan 1 kali penggorengan, 2 kali penggorengan, 9 kali penggorengan dan 10 kali penggorengan.. Suhu yang digunakan adalah suhu sekitar $174^{\circ} \mathrm{C}-186^{\circ} \mathrm{C}$. Minyak yang digunakan adalah minyak curah, dengan volume minyak sebanyak 1 liter. Waktu yang digunakan untuk menggoreng ayam adalah 5 menit sampai daging ayam matang sempurna. Kemudian dilakukan analisis mutu minyak goreng dengan parameter yang sesuai dengan SNI, diantaranya parameter kadar air, asam lemak bebas dan bilangan peroksida.

\section{Metodologi Penelitian}

Bahan kimia, peralatan dan instrumentasi Bahan-bahan yang digunakan adalah minyak goreng hasil penggorengan ayam dari 0 kali penggorengan sampai 10 kali penggorengan, alkohol netral 95\%, indikator fenolftalein, natrium hidroksida $(\mathrm{NaOH}) \quad 0,05 \mathrm{~N}$, natrium tiosulfat $\left(\mathrm{Na}_{2} \mathrm{~S}_{2} \mathrm{O}_{3}\right) \quad 0,05 \mathrm{~N}$, kalium iodida (KI) jenuh, kloroform, $\left(\mathrm{CHCl}_{3}\right)$, asam asetat glasial $\left(\mathrm{CH}_{3} \mathrm{COOH}\right)$, aquades, indikator amilum $1 \%$.

Alat-alat yang digunakan dalam penelitian ini adalah kompor, wajan, oven, neraca analitik, termometer $250 \mathrm{oC}$, buret, erlenmeyer, gelas ukur, cawan porselen, pipet volume, gelas kimia, desikator, hot plate.

\subsection{Prosedur penelitian \\ Penyiapan Kondisi Penggorengan}

Untuk Setiap Variasi perlakuan Sampel minyak goreng yang belum digunakan diambil sedikit sebagai sampel pada 0 kali penggorengan. Selanjutnya kompor dihidupkan dan diletakkan wajan diatas kompor tersebut. Kemudian diambil 1 liter minyak curah dan dipanaskan di dalam wajan dengan suhu $170^{\circ} \mathrm{C}-177^{\circ} \mathrm{C}$. Kemudian daging ayam dimasukkan ke dalam wajan dengan bobot \pm 300 gram ( \pm 5 potong daging ayam), pada saat penggorengan suhu yang digunakan adalah suhu sekitar $174^{\circ} \mathrm{C}-186^{\circ} \mathrm{C}$. Waktu yang digunakan untuk menggoreng ayam selama 5 menit sampai daging ayam matang sempurna, setelah mencapai waktu penggorengan ayam diangkat. Kemudian ditunggu sampai minyak pada wajan dingin dan diambil sedikit sampel minyak goreng sebagai sampel pada pengulangan 1 kali penggorengan untuk dianalisis mutunya. Penggorengan daging ayam pada minyak goreng dilakukan kembali dengan perlakuan pengulangan 2 kali penggorengan, 3 kali penggorengan, 4 kali penggorengan, 5 kali penggorengan, 6 kali penggorengan, 7 kali penggorengan, 8 kali penggorengan, 9 kali penggorengan dan 10 kali penggorengan.

\section{Kadar Air}

Pertama diaduk sampel dengan baik sebelum dilakukan pengujian dikarenakan air cenderung untuk mengendap. Lalu dipanaskan cawan porselen terlebih dahulu dalam oven dengan suhu $105^{\circ} \mathrm{C}$ selama 30 menit, kemudian didinginkan. Setelah itu ditimbang cawan porselen tersebut hingga diperoleh bobot konstan cawan kosong kering. Selanjutnya sampel minyak ditimbang seberat 2 gram didalam cawan tersebut, lalu dimasukkan ke dalam oven dan dikeringkan pada suhu $105^{\circ} \mathrm{C}$ selama 4 jam. Setelah itu diangkat sampel dari oven dan dinginkan sampai suhu kamar, lalu ditimbang kembali cawan tersebut. Pengeringan dilakukan sampai diperoleh bobot konstan (selisih 
penimbangan berturut-turut kurang dari $0,2 \mathrm{mg}$ ). Pengurangan berat merupakan banyaknya air dalam minyak. Penetapan kadar air dilakukan dalam ulangan 2 kali.

\section{Asam Lemak Bebas}

Minyak ditimbang sebanyak 2,5 gram dan dimasukkan dalam erlenmeyer. Kemudian ditambahkan $50 \mathrm{~mL}$ alkohol netral 95\% yang telah dipanaskan dan $2 \mathrm{~mL}$ indikator fenolftalein. Selanjutnya dititrasi dengan $0,1 \mathrm{~N} \mathrm{NaOH}$ standar sampai terjadi perubahan warna merah muda yang tidak hilang selama 0,5 menit. Penetapan dilakukan dengan pengulangan sebanyak 2 kali.

\section{Bilangan Peroksida}

Minyak goreng ditimbang sebanyak 10 gram kemudian dimasukkan ke dalam Erlenmeyer. Selanjutnya, ditambahkan $12 \mathrm{~mL}$ kloroform dan 18 $\mathrm{mL}$ asam asetat glasial ke dalam erlenmeyer tersebut. Selanjutnya tambahkan $0,5 \mathrm{~mL}$ larutan KI jenuh ditutup rapat sambil dikocok. Diamkan 1-2 menit di tempat gelap sambil sesekali dikocok, kemudian ditambahkan $30 \mathrm{~mL}$ aquades, dan 0,5 $\mathrm{mL}$ indikator amilum $1 \%$, terbentuk warna biru, kemudian dititrasi dengan Na2S2O3 0,05 N hingga warna biru hilang. Penetapan dilakukan dengan pengulangan sebanyak 2 kali. Dengan cara yang sama dibuat juga larutan blanko.

\section{Bilangan Iod}

Minyak goreng ditimbang sebanyak $5 \mathrm{~g}$ kemudian dimasukaa ke dalam Erlenmeyer bertutup. Selanjutnya ditambahkan $10 \mathrm{ml}$ kloroform dan $25 \mathrm{~mL}$ pereaksi wijs. Lalu disimpan dalam ruang gelap selama 30 menit dan sesekali dikocok. Kemudian ditambahkan $10 \mathrm{~mL}$ larutan KI $15 \%$ dan $50 \mathrm{~mL}$ aquades, dan $2 \mathrm{~mL}$ larutan amilum. Kemudian dilanjutkan dengan dititrasi dengan $\mathrm{Na}_{2} \mathrm{~S}_{2} \mathrm{O}_{3}$ 0,05 $\mathrm{N}$ sampai warna biru hilang.

Penetapan dilakukan dengan pengulangan sebanyak 2 kali. Dengan cara yang sama dibuat juga larutan blanko.

\section{Hasil dan Diskusi}

\subsection{Analisis Mutu Minyak}

\section{Analisa Kadar Air}

Kadar air adalah jumlah air yang terkandung dalam minyak yang menentukan mutu minyak. Prinsip penetapan kadar air dengan metode oven adalah menguapkan air yang terkandung dalam minyak dengan cara dikeringkan dalam oven selama kurang lebih 4 jam pada suhu $100-105^{\circ} \mathrm{C}$ untuk mendapatkan berat yang konstan. Air adalah konstituen yang keberadaannya dalam minyak sangat tidak diinginkan karena akan menghidrolisis minyak menghasilkan asam-asam lemak bebas yang menyebabkan bau tengik pada minyak. ${ }^{9}$ Minyak goreng yang mengandung kadar air yang tinggi mengalami penurunan kualitas karena semakin tinggi kadar air dalam minyak goreng maka akan semakin rendah kualitas dari minyak goreng tersebut sehingga minyak menjadi berbau tengik . ${ }^{10}$

Hasil pengukuran kadar air minyak goreng curah dapat dilihat pada Gambar 1.

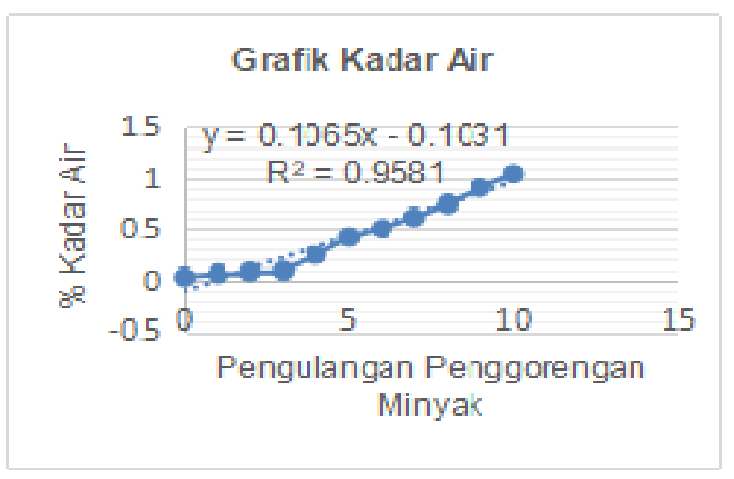

Gambar 1. Grafik Kadar Air Pada Setiap Pengulangan Penggorengan

Kadar air dihitung dari selisih bobot minyak sebelum air dalam minyak diuapkan dengan bobot minyak setelah air dalam minyak diuapkan. Hasil pengujian menunjukkan kadar air pada minyak goreng curah sebelum penggorengan, hasil penggorengan 1, penggorengan 2 dan penggorengan 3 memenuhi standar SNI 01-37412013 yaitu sebesar 0,15\% (b/b). Persentase kadar air tertinggi terdapat pada penggorengan 10 yaitu sebesar 1,04\% (b/b). Dan persentase kadar air terendah terdapat pada minyak sebelum penggorengan (minyak curah) yaitu sebesar $0,03 \%$ (b/b).

Berdasarkan standar SNI 01-3741-2013, standar kadar air pada minyak goreng yaitu $0,15 \%$ (b/b). Dari data diatas, hasil kadar air pada penggorengan 4 yaitu sebesar $0,24 \%$ (b/b) sudah melewati ambang batas persentase kadar air. Pada penggorengan 4 inilah minyak goreng mulai melewati ambang batas persentase kadar air. Tingginya kadar air dalam minyak dapat diperoleh 
dari bahan makanan yang digoreng, proses saat penggorengan atau kelembapan udara pada saat penyimpanan. Selama proses menggoreng, air dalam bahan pangan akan keluar dan diisi oleh minyak goreng sehingga menaikkan kadar air dalam minyak (Muallifah, 2009). Pada gambar tersebut memperlihatkan hasil analisa kadar air mengalami peningkatan yang signifikan, karena berkaitan dengan frekuensi penggorengan, hal ini menunjukkan bahwa semakin sering penggunaan minyak goreng memberikan efek sinergis meningkatnya kadar air yang kemungkinan dapat disebabkan adanya proses pencelupan bahan yang akan digoreng dengan tepung yang telah bercampur air.

Maka dapat disimpulkan bahwa kualitas minyak goreng berdasarkan kadar air yang sesuai dengan standar SNI 01-3741-2013 yaitu sebesar $0,03 \%$ (b/b) dimulai dari sebelum penggorengan sampai penggorengan 3, sedangkan pada penggorengan 4 kualitas minyak goreng sudah tidak baik karena sudah melewati ambang batas kadar air. Bahan pangan yang digoreng identik dengan kerenyahan dan tekstur yang keras berbeda dengan produk yang diolah dengan cara lain. Hal ini disebabkan kandungan air yang terdapat pada bahan pangan yang digoreng sangatlah sedikit. Hal ini dapat terjadi mengingat mengolah bahan pangan dengan menggoreng menggunakan media minyak atau lemak dan dengan suhu yang tinggi yang dapat menyebabkan air yang terkandung dalam bahan pangan dapat menguap.

\section{Analisa Kadas Asam Lemak Bebas (ALB)}

Asam lemak bebas erat kaitannya dalam mengukur kualitas minyak gorng. Asam lemak bebas merupakan hasil peruraian yang terjadi pada asam lemak yang disebabkan adanya reaksi kompleks pada minyak. Semakin tinggi kandungan asam lemak bebas pada minyak menandakan semakin menurunnya mutu dari minyak goreng tersebut.

Pada saat minyak digunakan, pada awal proses asam lemak bebas dihasilkan melalui proses pemecahan oksidasi. Namun, pada tahap selanjutnya asam lemak bebas dihasilkan dari proses hidrolisis yang disebabkan karena adanya air. Minyak yang digunakan dalam proses penggorengan memiliki resiko besar dalam terbentuknya asam lemak bebas karena adanya perlakuan panas dengan temperatur yang tinggi yang menyebabkan meningkatnya kandungan asam lemak bebas. Hal ini sesuai dengan pernyataan Andarwulan (1997), bahwa minyak goreng yang digunakan dalam proses penggorengan sejumlah besar akan dipanaskan pada suhu mencapai 1621960C dengan kondisi bahan pangan yang terendam dan digunakan secara kontinu akan menghasilkan asam lemak bebas pada minyak goreng tersebut.

Asam lemak bebas dalam minyak sawit ditetapkan kadarnya menggunakan titrasi dengan menggunakan pereaksi basa yaitu $\mathrm{KOH}$ atau $\mathrm{NaOH}$. Dalam prosedur analisis, fungsi penambahan etanol adalah untuk melarutkan lemak atau minyak dalam sampel agar dapat bereaksi dengan basa alkali. Etanol yang digunakan konsentrasinya berada di kisaran 95-96\%. Fungsi pemanasan pada saat percobaan adalah agar minyak larut seluruhnya dalam etanol dan reaksi berlangsung lebih cepat (Suroso, 2013).

Berdasarkan standar SNI 01-3741-2013, standar asam lemak bebas pada minyak goreng yaitu $0,6 \%(\mathrm{~b} / \mathrm{b})$. Dari data yang diperoleh asam lemak bebas pada minyak curah sebelum penggorengan, penggorengan 1 , penggorengan 2 dan penggorengan 3 masih memenuhi standar SNI 01-3741-2013. Persentase asam lemak bebas tertinggi terdapat pada penggorengan 10 yaitu sebesar $1,01 \%(b / b)$. Dan persentase asam lemak bebas terendah terdapat pada minyak sebelum penggorengan (minyak curah) yaitu sebesar $0,39 \%$ (b/b).

Hasil pengukuran asam lemak bebas (ALB) minyak goreng curah dapat dilihat pada Gambar 2 .

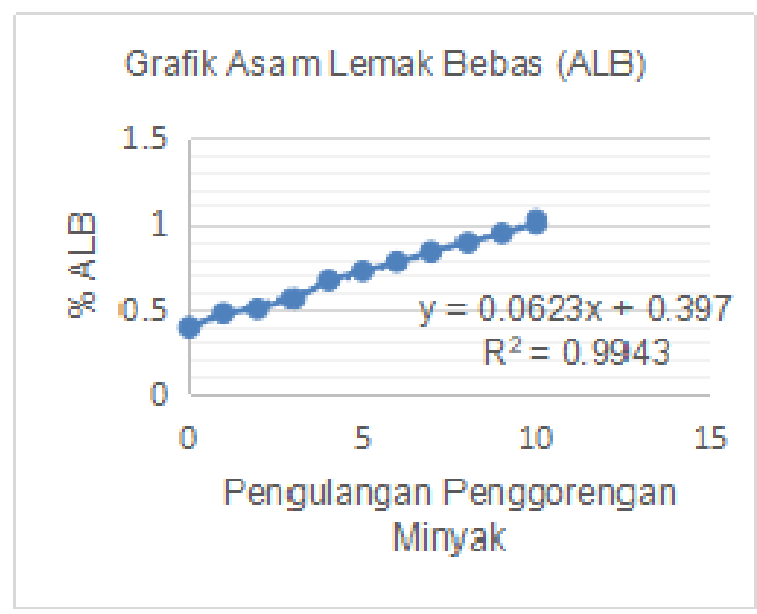

Gambar 2. Grafik Asam Lemak Bebas (ALB) Pada Setiap Pengulangan Penggorengan 
Berdasarkan standar SNI 01-3741-2013, standar kadar asam lemak bebas pada minyak goreng yaitu $0,6 \%(\mathrm{~b} / \mathrm{b})$. Dari data diatas, hasil asam lemak bebas pada penggorengan 4 yaitu sebesar $0,67 \%(\mathrm{~b} / \mathrm{b})$ sudah melewati ambang batas persentase asam lemak bebas. Pada penggorengan 4 inilah minyak goreng mulai melewati ambang batas persentase asam lemak bebas.

Hasil analisa diatas menunjukan peningkatan pada setiap perlakuan penggorengan terhadap nilai kandungan asam lemak bebas pada minyak goreng. Peningkatan persentase asam lemak bebas ini disebabkan adanya pertukaran komponen air pada bahan pangan yang digoreng dengan minyak yang dijadikan media penggorengan. Hal ini sesuai dengan penelitian Ketaren ${ }^{1}$, bahwa kerusakan yang terjadi pada minyak goreng yang digunakan berulang kali dalam proses penggorengan, disebabkan adanya reaksi kompleks yang terjadi pada saat bahan pangan digoreng. Adanya kandungan air dan udara pada bahan pangan semakin meningkatkan kerusakan yang terjadi pada minyak yang dapat dianalisa dengan menghitung kadar asam lemak bebas dari minyak tersebut. Menurut Sulieman et al.,(2001) bahwa kenaikan kadar asam lemak bebas karena pada saat awal penggorengan, kadar air dalam minyak belum terlalu banyak, tetapi pada proses penggorengan selanjutnya kadar air pada minyak semakin bertambah. Semakin lama penggunaan minyak untuk menggoreng, semakin tinggi pula kandungan asam lemak bebas yang terbentuk.

Maka dapat disimpulkan bahwa kualitas minyak goreng berdasarkan asam lemak bebas yang sesuai dengan standar SNI 01-3741-2013 yaitu sebesar $0,6 \%(\mathrm{~b} / \mathrm{b})$ dimulai dari sebelum penggorengan sampai penggorengan 3 , sedangkan pada penggorengan 4 kualitas minyak goreng sudah tidak baik karena sudah melewati ambang batas persentase asam lemak bebas. Asam lemak bebas merupakan hasil perombakan yang terjadi pada asam lemak yang disebabkan adanya reaksi kompleks pada minyak. Semakin tinggi kandungan asam lemak bebas pada minyak menandakan semakin menurunnya mutu dari minyak goreng tersebut. Reaksi hidrolisa yang terjadi pada minyak akan mengakibatkan kerusakan minyak karena terdapat sejumlah air dalam minyak tersebut dan menyebabkan terbentuknya asam lemak bebas dan beberapa gliserol (Muchtadi, 2009).

\section{Analisa Bilangan Peroksida}

Angka peroksida adalah nilai terpenting untuk menentukan derajat kerusakan minyak atau lemak yang didasarkan pada reaksi antara alkali iodida dalam larutan asam dengan ikatan peroksida. Asam lemak tidak jenuh dapat mengikat oksigen pada ikatan rangkapnya sehingga membentuk peroksida. Peroksida merupakan hasil oksidasi utama dari minyak goreng (Ketaren, 1986). Bilangan peroksida dapat diukur secara kuantitatif dengan menggunkan totrasi iodometri, dengan penentuan jumlah iodin yang dibebaskan menggunakan kalium iodida. Iodin yang telah dibebaskan dititrasi dengan natrium tiosulfat, selanjutnya ditambahkan indikator amilum hingga berwarna biru, kemudian dititrasi kembali dengan natrium tiosulfat hingga warna biru tepat menghilang. Nilai bilangan peroksida dinyatakan dalam miliekuivalen iodium per kilogram lemak (Day dan Underwood, 1981). Pengujian kadar bilangan peroksida merupakan nilai terpenting untuk menentukan derajat kerusakan pada minyak atau lemak (Ketaren, 1986).

Berdasarkan standar SNI 01-3741-2013, standar bilangan peroksida pada minyak goreng yaitu 10 mek O2/kg. Dari data yang diperoleh bilangan peroksida pada minyak curah sebelum penggorengan, penggorengan 1 , penggorengan 2 , penggorengan 3 dan penggorengan 4 masih memenuhi standar SNI 01-3741-2013. Persentase bilangan peroksida tertinggi terdapat pada penggorengan 10 yaitu sebesar 18,465 mek O2/kg. Dan persentase bilangan peroksida terendah terdapat pada minyak sebelum penggorengan (minyak curah) yaitu sebesar 5,99 mek O2/kg.

Hasil pengukuran bilangan peroksida minyak goreng curah dapat dilihat pada Gambar 3.

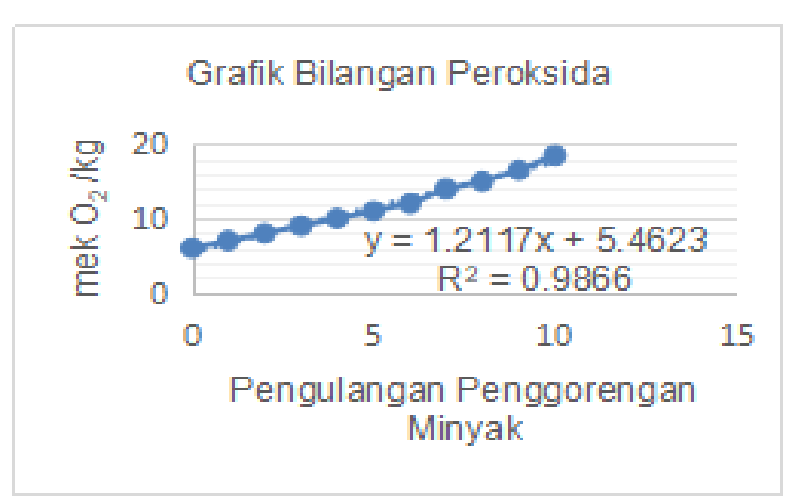

Gambar 3. Grafik Bilangan Peroksida Pada Setiap Pengulangan Penggorengan 
Berdasarkan standar bilangan peroksida sesuai SNI 01-3741-2013, yaitu sebesar 10 mek O2/kg. Dari data diatas, hasil bilangan peroksida pada penggorengan 5 yaitu sebesar 10,97 mek $\mathrm{O} 2 / \mathrm{kg}$ sudah melewati ambang batas persentase bilangan peroksida. Pada penggorengan 5 inilah minyak goreng mulai melewati ambang batas persentase bilangan peroksida.

Adanya proses penggorengan berulang kali pada minyak goreng mempengaruhi nilai bilangan peroksida pada minyak goreng tersebut. Menurut Kateran (2005), proses oksidasi berlangsung bila terjadi kontak antara sejumlah oksigen dengan minyak atau lemak, seiring dengan frekuensi dan lamanya penggorengan, minyak akan teroksidasi dan membentuk senyawa peroksida.

Hasil analisa diatas menunjukan peningkatan pada setiap perlakuan penggorengan terhadap nilai kandungan bilangan peroksida pada minyak goreng. Peningkatan persentase bilangan peroksida ini disebabkan karena adanya perlakuan penggorengan yang berulang kali pada minyak goreng, semakin lamanya waktu yang digunakan dalam proses penggorengan, berdasarkan banyaknya frekuensi penggorengan sehingga minyak goreng akan mengalami proses oksidasi, karena adanya kontak dengan udara dan mutu minyak goreng menurun. Menurut Ketaren (1986), bahwa terjadinya oksidasi pada minyak goreng oleh oksigen bila bahan dibiarkan kontak dengan udara.

Bilangan peroksida yang tinggi menandakan minyak telah teroksidasi ditandai dengan rasa dan bau tengik. Trigliserida yang memiliki rantai tidak jenuh (rangkap) mengalami autooksidasi membentuk radikal-radikal bebas. Jenis radikal yang terbentuk dalam proses peroksida menurunkan lemak asam dan komponen lain dari lipid. Proses ini dapat dipercepat dengan adanya cahaya, panas, peroksida lemak atau hidroperoksida serta logam berat (seperti $\mathrm{Cu}, \mathrm{Fe}$, Co dan Mn). Proses selanjutnya yang terjadi adalah terbentuk senyawa hidroperoksida yang kemudian dipecah membentuk senyawa- senyawa aldehid. Senyawa-senyawa aldehid ini memberikan bau tengik dan bersifat toksik. Bilangan peroksida yang tinggi dan bau tengik yang terbentuk memandakan bahwa minyak jelantah hitam dan coklat sudah tidak bisa digunakan kembali karena bersifat toksik yang dapat membahayakan kesehatan.
Maka dapat disimpulkan bahwa kualitas minyak goreng berdasarkan bilangan peroksida yang sesuai dengan standar SNI 01-3741-2013 yaitu sebesar $10 \mathrm{mek} \mathrm{O} / \mathrm{kg}$, dimulai dari sebelum penggorengan sampai penggorengan 4, sedangkan pada penggorengan 5 kualitas minyak goreng sudah tidak baik karena sudah melewati ambang batas persentase bilangan peroksida. Oksidasi lemak oleh oksigen terjadi secara spontan jika bahan berlemak dibiarkan kontak dengan udara, sedangkan kecepatan oksidasinya tergantung pada tipe lemak dan kondisi penyimpanan (Ketaren, 1986). Minyak goreng curah terdistribusi tanpa kemasan, paparan oksigen dan cahaya pada minyak curah lebih besar dibandingkan minyak kemasan. Paparan oksigen, cahaya, dan suhu tinggi merupakan beberapa faktor yang mempengaruhi oksidasi (Lempang, 2016).

\section{Analisa Bilangan Iod}

Bilangan iod digunakan untuk menentukan ketidakjenuhan dan ketengikan minyak goreng, makin tinggi bilangan iod makin lanjut proses ketengikan yang terjadi pada minyak goreng. Ketengikan yang diartikan sebagai kerusakan atau perubahan bau dan rasa (flavour) dalam minyak (Margaretha, 1992). Derajat ketidakjenuhan asam lemak yang menyusun minyak dapat ditentukan berdasarkan reaksi adisi antara asam lemak dengan iodin (Kusnandar, 2010). Pengamatan bilangan iod dilakukan dengan metode Wijs (Ketaren, 1986), dimana ion iod ditambahkan secara berlebih dan dipergunakan sebagai sebuah agen pereduksi (iodometri), selanjutnya kelebihan dari ion iodin ditambahkan kedalam agen pengoksidasi yang sedang ditentukan, selanjutnya I2 akan mengadisi ikatan rangkap asam lemak tidak jenuh yang kemudian dititrasi dengan natrium tiosulfat (Day 6 dan Underwood, 1981) sehingga iod yang diabsorpsi oleh minyak dapat diketahui jumlahnya.

Minyak goreng bekas bilangan iodnya memiliki nilai sangat rendah karena ikatan rangkap pada minyak goreng bekas semakin kecil. Angka iod menunjukkan ketidakjenuhan asam lemak penyusun minyak dan lemak. Asam lemak tidak jenuh mampu mengikat iod dan membentuk senyawa yang jenuh. Banyaknya iod yang diikat menunjukkan banyaknya ikatan rangkap yang terdapat pada minyak. Angka iod dinyatakan sebagai banyaknya gram iod yang diikat oleh 100 gram minyak atau lemak. Hal ini menunjukkan 
bahwa semakin tinggi angka iod, semakin bagus kualitas minyak goreng. Hal ini sesuai pendapat Sudarmadji (2003), bahwa angka iodin mencerminkan ketidak jenuhan asam lemak penyusun minyak. Asam lemak tidak jenuh mampu mengikat iod dan membentuk senyawaan yang jenuh. Banyaknya iodin yang diikat menunjukkan banyaknya ikatan rangkap.

Berdasarkan standar SNI 01-3741-2013, standar bilangan iod pada minyak goreng yaitu 45-

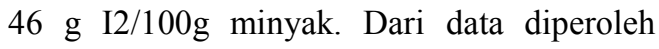
hasil bilangan iod pada minyak curah sebelum penggorengan sampai penggorengan 10 masih memenuhi standar SNI 01-3741-2013. Persentase bilangan iod tertinggi terdapat pada minyak curah (sebelum penggorengan) yaitu sebesar 3,55 g I2/100g minyak. Dan persentase bilangan iod terendah terdapat pada minyak hasil penggorengan 10 yaitu sebesar $3,255 \mathrm{~g} \mathrm{I} / 100 \mathrm{~g}$ minyak.

Hasil pengukuran bilangan iod minyak goreng curah dapat dilihat pada Gambar 4.

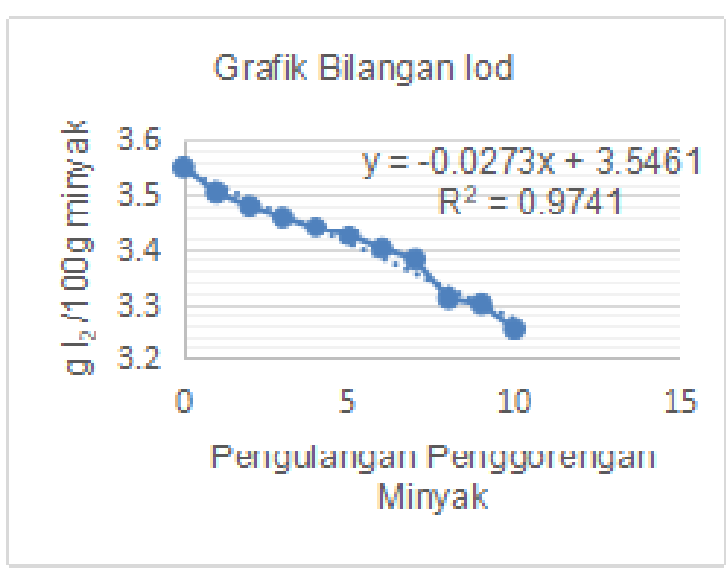

Gambar 4. Grafik Bilangan Iod Pada Setiap Pengulangan Penggorengan

Kadar bilangan iod pada minyak curah sebelum penggorengan merupakan yang paling terbesar yaitu sebesar 3,55 g I2/100g minyak, hal ini menunjukkan bahwa minyak curah sebelum penggorengan yang memiliki kualitas paling bagus dibandingkan dengan minyak yang telah dilakukan penggorengan. Hal ini sesuai dengan pendapat Sudarmadji (2007), bahwa semakin tinggi angka iod, semakin bagus kualitas minyak goreng.

Jika di amati pada gambar nilai bilangan iod memiliki nilai yang beragam dan semakin menurun hingga penggorengan 10 . Hal ini sesuai pendapat Austutik (2010), bahwa minyak goreng bekas memiliki angka iod yang sangat rendah. Hal ini dikarenakan jumlah ikatan rangkap dalam minyak goreng bekas semakin kecil sebagai akibat dari pemanasan dengan suhu tinggi dan pemakaian minyak yang lebih dari 10 kali penggorengan.

Maka dapat disimpulkan dari gambar diatas bahwa kualitas minyak goreng berdasarkan bilangan iod pada semua minyak goreng dimulai dari sebelum penggorengan sampai minyak hasil penggorengan ke 10 kali masih memenuhi standar SNI 01-3741-2013 yaitu sebesar 45-46 g I2/100g minyak. Bilangan iodine menunjukkan derajat ketidakjenuhan asam lemak penyusun minyak. Asam lemak tidak jenuh mampu mengikat iodium dan membentuk persenyawaan yang jenuh. Banyaknya iodine yang diikat menunjukkan banyaknya ikatan rangkap dimana asam lemak tidak jenuh mampu mengikat iodium dan membentuk persenyawaan yang jenuh (Noriko, 2012).

\section{Kesimpulan}

Pada minyak goreng dilakukan 4 uji yaitu uji kadar air, Asam Lemak Bebas (ALB), bilangan peroksida dan bilangan iod. pengulangan penggorengan ayam menggunakan minyak goreng curah yang masih memenuhi standar mutu minyak SNI 01-3741-2013 yaitu pada uji kadar air sampai pada minyak hasil penggorengan 3, pada uji Asam Lemak Bebas (ALB) sampai pada minyak hasil penggorengan 3 , dan pada uji bilangan peroksida sampai pada minyak hasil penggorengan 4. Dan pada uji bilangan iod kualitas minyak masih bagus, dimana minyak sebelum penggorengan memiliki kualitas bilangan iod yang lebih bagus sesuai dengan standar mutu minyak SNI 01-3741-2013.

\section{Acknowledgement}

Ucapan terima kasih penulis kepada Tuhan Yang Maha Esa yang telah memberikan segala berkat dan rahmat-Nya sehingga penelitian ini dapat terselesaikan dengan baik. Terimakasih juga kepada laboratorium Kimia, Universitas Negeri Medan yang telah memberikan fasilitas untuk penelitian ini.

\section{Referensi}

1. Ketaren. S. (2008). Minyak dan Lemak Pangan. Jakarta: UI Press.

2. Kapitan. B.O. (2013). "Analisis Kandungan Asam Lemak Trans (Trans Fat) Dalam Minyak Bekas Penggorengan Jajanan Di 
Pinggir Jalan Kota Kupang.” Jurnal Kimiaterapan. 1(1), pp. 17-31.

3. Kusumaningtyas. R. Qudus. N. Putri. D. dan Kusumawardani. R. (2018). "Penerapan Teknologi Pengolahan Limbah Minyak Goreng Bekas Menjadi Sabun Cuci Piring Untuk Pengendalian Pencemaran Dan Pemberdayaan Masyarakat." Jurnal Abdimas. 22(2), pp. 201- 208.

4. Wardana, D., Ramadhan, A., Amne, D.P.F. \& Eddyanto. (2019). Utilization of Glycerol from Used Oil as an Ester Glycerol Surfactant. Indonesian Journal of Chemical Science and Technolog, 2(2): 111-120.

5. Syafiq. A. (2007). Gizi dan Kesehatan Masyarakat Edisi Revisi. Jakarta: Raja Grafindo Persada.

6. Ardhany. S. dan Lamsiyah. (2018). "Tingkat Pengetahuan Pedagang Warung Tenda Di Jalan Yos Sudarso Palangkaraya tentang Bahaya Penggunaan Minyak Jelantah Bagi Kesehatan." Jurnal Surya Medika. 3(2), pp. 62-68.

7. Zahra. S. Dwiloka. B. dan Mulyani, S. (2013). "Pengaruh Penggunaan Minyak Goreng Berulang Terhadap Perubahan Nilai Gizi Dan Mutu Hedonik Pada Ayam Goreng." Animal Agriculture Journal. 2(1), pp. 253-260.

8. Damanik, M. \& Murkovic, M. (2019). Derivatisation of 2,4 (dinitrophenyl hydrazine) DNPH in Canola Oil Oxidation. Indonesian Journal of Chemical Science and Technology, 2(1): 80-83.

9. Poedjiadi. A. (1999). Dasar-Dasar Biokimia. Jakarta: UI-Press.

10. Fanani. N. dan Ningsih. E. (2018). "Analisis Kualitas Minyak Goreng Habis Pakai yang Digunakan oleh Pedagang Penyetan didaerah Rungkut Surabaya Ditinjau dari Kadar Air dan Kadar Asam Lemak Bebas (ALB)." Jurnal IPTEK, 22(2).

11. Muchtadi. D. (2009). Pengantar Ilmu Gizi. Bandung: CV. Alfabeta.

12. Lempang. I. Fatimawali. dan Pelealu. N. (2016). "Uji Kualitas Minyak Goreng Curah Dan Minyak Goreng Kemasan Di Manado.” Jurnal Ilmiah Farmasi, 5(4), pp. 155-161.

13. Sudarmadji. S. Haryono. dan Suhardi. (2007). Analisis Bahan Makanan dan Pertanian. Yogyakarta: Liberty. 